\title{
EKSISTENSI DAN PERUBAHAN FUNGSI JUKUNG BAGI MASYARAKAT BANJAR
}

Oleh:

\section{Risma Ariyani}

NIM. 1810111220028

Email: 1810111220028@mhs.ulm.ac.id

Program Studi Pendidikan Sejarah Fakultas Keguruan Dan Ilmu Pendidkan

Universitas Lambung Mangkurat

Banjarmasin

\begin{abstract}
Abstrak
Kemajuan teknologi sangat berdampak pada berbagai aspek kehidupan. Penemuan-penemuan yang muncul semakin canggih dengan tawaran kemudahannya. Begitu pula perubahan dan pembaruan pada moda tansportasi yang semakin mempermudah manusia dalam hal mobilitas. Artikel ini menggunakan pendekatan kualitatif deskriptif untuk menggambarkan bagaimana perubahan fungsi jukung dimasa sekarang. Hasil dari proses analisis ini menggambarkan bahwa kemajuan teknologi transportasi juga berdampak pada transportasi sungai masyarakat lokal Banjar yaitu jukung. Masyarakat Banjar telah dimudahkan dengan banyak akses jalur darat dan teknologi transportasi darat sebagai pendukungnya, sehingga eksistensi jukung semakin meredup.

Kata kunci: Jukung, Perubahan, Masyarakat Banjar, Transportasi, Sungai

\section{Pendahuluan}

Transportasi merupakan media yang digunakan untuk melakukan perpindahan dari suatu tempat ke tempat lain, baik itu berupa barang maupun manusia. Hal ini sejalan dengan peran transportasi yang dijelaskan oleh Subiyakto dan Mutiani (2019:15) bahwa "ada dua peran transportasi bagi keidupan manusia diantaranya: (1) sebagai alat bantu untuk mengarahkan pembangunan di daerah
\end{abstract}


perkotaan, (2) sebagai prasarana bagi pergerakan manusia dan barang yang timbul akibat adanya kegiatan di daerah perkotaan tersebut". Di era modernisasi, perubahan pada moda transportasi begitu cepat. Inovasi-inovasi terus menerus dilakukan mengiringi kemajuan teknologi. Seiring perkembangan itu, manusia mulai merubah pola pikir untuk melakukan aktivitas yang lebih efisien waktu, dan praktis. Seperti halnya dengan penggunaan transportasi, manusia akan lebih memilih moda transportasi dengan mobilitas yang cepat dan berjangkauan luas.

Di wilayah Kalimantan, jika dilihat dari faktor geografis pada masa lalu wilayah daratan cendereung bervegetasi padat dan lebat. Sehingga jalur utama yang memungkinkan untuk melakukan mobilitas melalui sungai. Sama halnya dengan pernyataan Shang \& Zhang (dalam Subiyakto dan Mutiani, 2019:18) bahwa, "sungai menjadi satu jalur alternatif yang dilalui moda transportasi untuk mengangkut barang dan orang hingga saat ini”. Sebagai negara kepulauan, Indonesia memiliki persentase wilayah laut cenderung luas sehingga tidak heran jika orang-orang terdahulu memanfaatkan laut untuk jalur transportasi.

Transportasi sungai sederhana yang umum digunakan oleh orang-orang zaman dulu berupa rakit atau perahu ukuran kecil dengan menggunakan tenaga manusia itu sendiri. Di Kalimantan, alat transportasi ini disebut dengan jukung. Jukung merupakan alat transportasi sungai tradisional khas budaya masyarakat Banjar sejak masa lampau. Dijelaskan oleh Sari, dkk. (2019:11) bahwa "dalam studi sejarah dan arkeologi peninggalan-peninggalan jukung atau perahu sebagai artefak benda bergerak dapat mengungkapkan peristiwa-peristiwa sosial, ekonomi, budaya dan politik dimasa lampau dalam lingkungan geografis etnik pendukungnya ataupun dalam lingkungan yang lebih luas yang berkaitan dengan fakta migrasi di masa lampau”. Hal ini menggambarkan bahwa jukung merupakan hasil karya dari kebudayaan masyarakat seribu sungai berdasarkan hasil adaptasi dengan lingkungan yang didominasi oleh aliran sungai.

Seiring kemajuan zaman, jukung mengalami perubahan fungsi dan kegunaannya. Masa sekarang ini, jukung tidak lagi sepenuhnya digunakan untuk 
transportasi umum masyarakat Banjar, disebabkan adanya perpindahan moda transportasi dari sungai ke darat, hal ini karena banyaknya akses darat yang mudah dijangkau dibandingkan zaman dulu. Selebihnya, fungsi jukung sekarang hanya digunakan untuk berdagang dalam skala kecil dan pada waktu-waktu tertentu saja seperti pedagang-pedagang yang menggunakan jukung di Pasar Terapung.

\section{Pembahasan}

\section{Jukung Hasil Karya Urang Banjar di Kota Seribu Sungai}

Kalimantan tumbuh dengan sebutan kota seribu sungai. Sungai ini menjadi pusat atau sumber penghidupan bagi masyarakat Banjar. Berbagai aktivitas dilakukan di sungai hingga menjadikan kebudayaan masyarakat tepian sungai sebagai ciri khas urang Kalimantan. Dipaparkan oleh Putro (2020:2) bahwa, "the rivers have been a centre of social, political, economical and cultural activities connecting the hick and esturay od the river". Berarti bahwa sungai sangat berarti sebagai pusat aktivitas sosial, politik, ekonomi, dan budaya yang menghubungkan udik dan muara sungai. Hal ini sejalan dengan pemaparan Saleh (dalam Putro, 2020:6) bahwa, "as a result of natural conditions, thick jungle, the difficulty of transportation, the river becomes an important factor for traffic, trade, investment powers, cultural inclusion from the outside by foreign traders. Community at the estuary of the river has occurred long enough Hikayat Banjar (1968) describes the presence of groups of people at the estuary of the river in South Kalimantan and makes the estuaries of the river as a villages, trading center, and the center of power". Sebagai masyarakat yang hidup di wilayah sungai, ada proses timbal balik yang dilakukan sebagai makhluk sosial. Proses adaptasi yang lahir akibat dari penyesuaian terhadap lingkungan yang didominasi oleh sungai. Salah satu bentuk adaptasi tersebut ialah lahirnya budaya merakit jukung.

Jukung Tradisional merupakan produk budaya Banjar manusia sejak masa prsasejarah ketika manusia baru menemukan moda transportasi air menjelang berakhirnya kala Neolitik, sesudah penggunaan rakit-rakit bambu (Sari, dkk., 
2019:11). Dapat dikatakan bahwa jukung merupakan suatu olahan atau pembaruan dari rakit sederhana yang diikat oleh tali, hasil dari proses adaptadi masyarakat pinggiran sungai. Dalam konteks historis, jukung berkembang sebagai tanda perkembangan budaya banjar sejak jaman Daha di Nagara (Subiyakto dan Mutiani, 2019:40). Dan pendapat ini sejalan dengan Ridhoni (3) bahwa perkembangan jukung yang sampai ke Kalimantan Selatan akhirnya menjadi identitas budaya saat berdirinya kerajaan Dipa di Amuntai, lalu kerajaan Daha di Nagara, Hulu Sungai Selatan hingga, kerajaan Banjar di kuin, yang menjadi tonggak lahirnya suku banjar. Budaya sungai dan alat transportasinya tidak bisa dipisahkan dalam sistem sosial masyarakat Banjar ketika itu. Hal tersebut menggambarkan bahwa dengan adanya jukung melahirkan budaya Banjar dan menjadi bukti sejarah kehidupan sosial masa lampau di wilayah Kalimantan Selatan.

Salah satu wilayah yang masih melestarikan pembuatan jukung ialah Pulau Sewangi di sebuah desa yang ada di Kecamatan Alalak, Kabupaten Barito Kuala, Provinsi Kalimantan. "Sewangi Island is known as an island that produces river transportation modes, namely jukung” (Subiyakto, 2020:102). Pulau Sewangi merupakan wilayah yang masih melestarikan budaya merakit jukung ini hingga sekarang. Hingga saat ini membuat jukung masih menjadi sumber mata pencaharian sebagian masyarakat lokal Pulau Sewangi. Hal ini, dapat menjadi suatu langkah yang baik dalam upaya pelestarian jukung di bumi Borneo ini.

\section{Perubahan Fungsi Jukung di Tengah Kemajuan Teknologi Transportasi}

Dahulu jukung mempunyai peranan penting bagi masyarakat daerah Banjar, tapi sekarang budaya jukung semakin memudar dan diabaikan oleh masyarakat Kalimantan itu sendiri (Subiyakto dan Mutiani, 2019:39). Dewasa ini, penggunaan jukung tidak lagi sebagai moda transportasi utama masyarakat Banjar. Jarang ditemui hamparan jukung seperti halnya dahulu. Persentase jumlah produksi jukung juga menurun seiring bertambahnya kemajuan dan inovasi pada transportasi. Menurut Jarkasi (2012; dalam Ridhoni:3), budayawan Kalimantan 
Selatan, menyebut budaya jukung sebagai harmoni dalam kehidupan masyarakat Banjar. Budaya ini sudah sepatutnya terus dilestarikan sebagai identitas masyarakat seribu sungai.

Pada awalnya, penggunaan jukung sangatlah krusial bagi masyarakat Banjar untuk melakukan proses bersosial, dan keperluan masyarakat dalam konteks ekonomi. Masyarakat lokal memanfatkan jukung sebagai moda transportasi baik hanya untuk mobilitas maupun untuk perdagangan. Segala aktivitas masyarakat Banjar, sebagian besar bergantung pada sungai. Siring perkembangan zaman, pembangunan meningkat diberbagai wilayah yang tidak lain merupakan salah satu imbas dari proses kolonialisasi Bangsa Barat. Akses perjalanan darat yang mulai berkembang, secara berangsur-angsur mulailah masyarakat Banjar mengurangi intensitas penggunaan jukung karena telah dimudahkan oleh berbagai pembaruan khususnya pada alat transportasi. Sekarang ini, kehadiran dan eksistensi jukung hanya dapat dilihat dan dinikmati di bebrapa wilayah saja, sebagai bentuk dari program wisata Banjarmasin yaitu Pasar Terapung.

\section{Simpulan}

Berdasarkan pembahasan diatas dapat disimpulkan bahwa perubahan pada moda transportasi seiring perkembangan teknologi semakin memudahkan segala aktivitas manusia. Moda transportasi lokal dan manual dengan tenaga manusia seperti jukung sudah mulai ditinggalkan karena digantikan oleh transportasi darat yang lebih canggih. Hal ini juga disebabkan oleh adanya pembangunan akses darat yang mempermudah mobilitas masyarakat Banjar. Dengan adanya fenomena ini diharapkan jukung sebagai hasil karya Urang Banjar terdahulu terus dilestarikan dan dioptimalkan penggunannya sebagai penggambaran wilayah dengan sebutan “Kota Saribu Sungai”.

\section{Daftar Pustaka}


Putro, H. P. N., \& Jumriani, J. (2020). KEHIDUPAN SOSIAL DAN EKONOMI MASYARAKAT BANTARAN SUNGAI SEBAGAI SUMBER BELAJAR IPS.

Putro, H. P. N. (2020). Revitalisasi Nilai-Nilai Transportasi Tradisional dalam Pembelajaran IPS di Kalimantan Selatan.

Putro, H. P. N. (2020). RIVER IN SOUTH KALIMANTAN IN HISTORICAL PERSPECTIVE.

Ridhoni, I. JUKUNG DALAM PERSPEKTIF NILAI SOSIAL MASYARAKAT BANJAR DI DESA PULAU SEWANGI. Jurnal Socius, 5(2).

Sari, D. N. I., Sobatnu, F., \& Inayah, N. (2019). Sistem Informasi Geografis Jukung Pedagang Pasar Terapung Kuin Kota Banjarmasin. Jurnal ELTIKOM: Jurnal Teknik Elektro, Teknologi Informasi dan Komputer, 3(1), 9-16.

Subiyakto, B., Mutiani, M., Faisal, M., \& Mutaqin, M. A. (2020). Social Interaction of Jukung Craftsmen in Pulau Sewangi, Alalak, Barito Kuala. The Innovation of Social Studies Journal, 1(2), 102-110.

Subiyakto, B., \& Mutiani, M. (2019). EKSISTENSI USAHA PEMBUATAN JUKUNG DI PULAU SEWANGI, ALALAK, BARITO KUALA. 